\title{
Geochemistry of acid mine drainage from a coal mining area and processes controlling metal attenuation in stream waters, southern Brazil
}

\author{
VERIDIANA P. CAMPANER ${ }^{1}$, WANILSON LUIZ-SILVA ${ }^{1}$ and WILSON MACHADO ${ }^{2}$ \\ ${ }^{1}$ Universidade Estadual de Campinas, Instituto de Geociências, Departamento de Geologia e Recursos Naturais, \\ Rua João Pandiá Calógeras, 51, Cidade Universitária Zeferino Vaz, 13083-970 Campinas, São Paulo, Brasil \\ ${ }^{2}$ Universidade Federal Fluminense, Instituto de Química, Departamento de Geoquímica, Campus do Valonguinho, \\ Outeiro de São João Batista, s/n, Centro, 24020-150 Niterói, RJ, Brasil
}

Manuscript received on September 18, 2012; accepted for publication on May 8, 2013

\begin{abstract}
Acid drainage influence on the water and sediment quality was investigated in a coal mining area (southern Brazil). Mine drainage showed $\mathrm{pH}$ between 3.2 and 4.6 and elevated concentrations of sulfate, As and metals, of which, $\mathrm{Fe}, \mathrm{Mn}$ and $\mathrm{Zn}$ exceeded the limits for the emission of effluents stated in the Brazilian legislation. Arsenic also exceeded the limit, but only slightly. Groundwater monitoring wells from active mines and tailings piles showed $\mathrm{pH}$ interval and chemical concentrations similar to those of mine drainage. However, the river and ground water samples of municipal public water supplies revealed a $\mathrm{pH}$ range from 7.2 to 7.5 and low chemical concentrations, although $\mathrm{Cd}$ concentration slightly exceeded the limit adopted by Brazilian legislation for groundwater. In general, surface waters showed large $\mathrm{pH}$ range (6 to 10.8), and changes caused by acid drainage in the chemical composition of these waters were not very significant. Locally, acid drainage seemed to have dissolved carbonate rocks present in the local stratigraphic sequence, attenuating the dispersion of metals and As. Stream sediments presented anomalies of these elements, which were strongly dependent on the proximity of tailings piles and abandoned mines. We found that precipitation processes in sediments and the dilution of dissolved phases were responsible for the attenuation of the concentrations of the metals and As in the acid drainage and river water mixing zone. In general, a larger influence of mining activities on the chemical composition of the surface waters and sediments was observed when enrichment factors in relation to regional background levels were used.
\end{abstract}

Key words: acid mine drainage, coal, metals, water quality.

\section{INTRODUCTION}

The presence of high concentrations of trace elements dissolved in surface and ground waters is one of the main problems associated with acid drainage generated in coal and sulfide mining areas. Acid mine drainage (AMD) results from the oxidation of sulfides, typically pyrite, and is

Correspondence to: Wanilson Luiz-Silva

E-mail:wanilson@ige.unicamp.br characterized by low $\mathrm{pH}$ and high concentrations of $\mathrm{SO}_{4}{ }^{2-}, \mathrm{Fe}$, metalloids, and many metals (Larsen and Mann 2005). Abandoned mines and tailings piles can be sources for AMD and represent risk to the equilibrium of different ecosystems (Moncur et al. 2005, Cravotta 2008), especially when efficient mitigating actions against acidity are not applied. These actions can include the neutralization of acid drainage by means of limestone, hydrated 
lime, ammonia, and fly ash (Akcil and Koldas 2006, Fungaro and Izidoro 2006). In some cases, however, the attenuation of acidity may take place naturally if carbonate rocks present in the local stratigraphic sequence interact with AMD (Wicks and Groves 1993, Webb and Sasowsky 1994, Campaner and Luiz-Silva 2009). In general, the attenuation results from the increase in $\mathrm{pH}$ and decrease in the solubility of metals and metalloids, and depends strongly on the nature and abundance of neutralizing materials (Cravotta et al. 1999).

In natural drainage systems affected by AMD, the concentrations of some trace elements (e.g., As, $\mathrm{Cd}, \mathrm{Cu}, \mathrm{Ni}$, and $\mathrm{Pb}$ ) can be minimized as a result of various mechanisms inherent to the water system. Physico-chemical conditions frequently favor chemical equilibrium and precipitation of these metals a few meters downstream from the acid discharge, removing chemical species in solution (Paulson and Balistrieri 1999, Chon and Hwang 2000, Butler et al. 2008). The adsorption and co-precipitation of elements in mineral phases are particularly important mechanisms (Rose et al. 1979, Lee and Chon 2006). Iron and Mn oxy-hydroxides, for example, are important compounds involved in metal retention in sediments from fluvial systems, due to their high specific surface, tendency to form colloids and cation exchange capacity (Horowitz 1991, Cravotta 2008). In the interface with water, the surface of these mineral phases can be deprotonated under high $\mathrm{pH}$, or protonated under low $\mathrm{pH}$ conditions, making the surface more negative or more positive, respectively. At neutral to alkaline conditions, cationic trace metals tend to be adsorbed by surface negative charges, whereas oxyanions such as sulfate, arsenide and arsenate tend to be adsorbed by surface positive charges under low $\mathrm{pH}$ conditions (Stumm and Morgan 1996, Cravotta 2008). Additionally, the accumulation of metals in fluvial sediments affected by AMD can reach very high levels, with the possibility of desorption and risk of incorporation by living organisms (Stecko and Bendell-Young 2000).
Mineral coal in Brazil represents one of the major sources of non-renewable energy, and is especially used in thermoelectric power plants. The coal reserves of the country are 32 billions $t$, distributed in the states of Rio Grande do Sul (28 billions t), Santa Catarina (3.3 billions t), Paraná (103 millions $\mathrm{t})$ and São Paulo (8.5 millions t) (Gomes et al. 2003). In response to the need to expand the electricity supply, proposals exist to increase the coal-fired power stations, which should promote an increase in coal consumption from ca. 6 millions t year ${ }^{-1}$ (2006) to 13.6 millions t year $^{-1}$ in 2016, according to the Brazilian Ten-Year Energy Expansion Plan (2007-2016; Brazil 2007).

The Figueira region, state of Paraná, is one example of a Brazilian region affected by bituminous coal mining activities, with mines exploited since the mid 1990's. High levels of As (253 to $2176 \mathrm{mg} \mathrm{kg}^{-1}$ ), $\mathrm{Pb}$ (118 to $340 \mathrm{mg} \mathrm{kg}^{-1}$ ) and $\mathrm{Zn}$ (54.4 to $544 \mathrm{mg} \mathrm{kg}^{-1}$ ) have been found in its coal (Campaner and LuizSilva 2009). However, studies on the environmental impact by coal mining are relatively recent in Brazil (Teixeira et al. 2000, Pampêo et al. 2004). Special attention has been given to acid drainage remediation (Fungaro and Izidoro 2006, Soares et al. 2006, Church et al. 2007), but few studies have focused on the regional characterization of water systems and AMD influence on their physico-chemical conditions. The main objective of this study was to evaluate the possible influence of the acid drainage coming from a mining area within the Figueira region on the quality of surface and ground waters particularly in relation to metals and As. Since fluvial sediments can act as a sink or a source of the elements of interest for the surface waters, possible geochemical anomalies of metals and As in sediments potentially affected by AMD were also evaluated.

\section{STUDY AREA}

The study area is located in the Figueira region, north of the state of Paraná, southern Brazil (Fig. 1), where coal deposits have been exploited since the 1940's. 
This energy source has supplied a thermoelectric plant installed in the region by the end of the 1950's. The coal has been mined from open pits and galleries. Only a mine adit (named Mina 07, which will be replaced by a new mine adit in the next years) is in operation at present, producing ca. 97,000 $\mathrm{t} \mathrm{year}^{-1}$ and generating ca. $620 \mathrm{t}$ of tailings daily (V.P. Campaner and A. Spoladore, unpublished data). The pyrite-rich coal layers are up to $0.5 \mathrm{~m}$ thick and are found in the Rio Bonito Formation (of EoPermian age) of the Paraná Basin (Ordovician to Cretaceous; Ricardi-Branco et al. 2002, Jasper et al. 2011). The Rio Bonito Formation is divided into a basal unit, the Triunfo Member, where sandstones, shales and coal predominate; an intermediate unit, the Paraguaçu Member, constituted by siltstones and shales intercalated with thin sandstones and carbonate lenses; on top there is the Siderópolis Member, represented by very thin sandstones. The latter is poorly developed in the study area (Morrone and Daemon 1985). Data from drill holes in the Mina 07 area revealed a sedimentary sequence (ca. $38 \mathrm{~m}$ ) overlying the coal layers formed by alternating metersized sandstone and siltstone layers, both occasionally calciferous at the base. In this sequence centimetersized impure limestone lenses occur (Campaner and Luiz-Silva 2009).

AMD remedial actions in this area are limited to acidity neutralization by applying a commercial product resulting from the calcination of calcareous rock (high $\mathrm{CaO}$ and $\mathrm{MgO}$ contents), and disposal of tailings between compacted soil layers, thus reducing its exposure to oxygen and rain water. Recently, Campaner and Luiz-Silva (2009) showed that the presence of limestone in the Mina 07 stratigraphy also contributes to the $\mathrm{pH}$ increase in acid flows discharged in the natural drainage, minimizing regional impact.

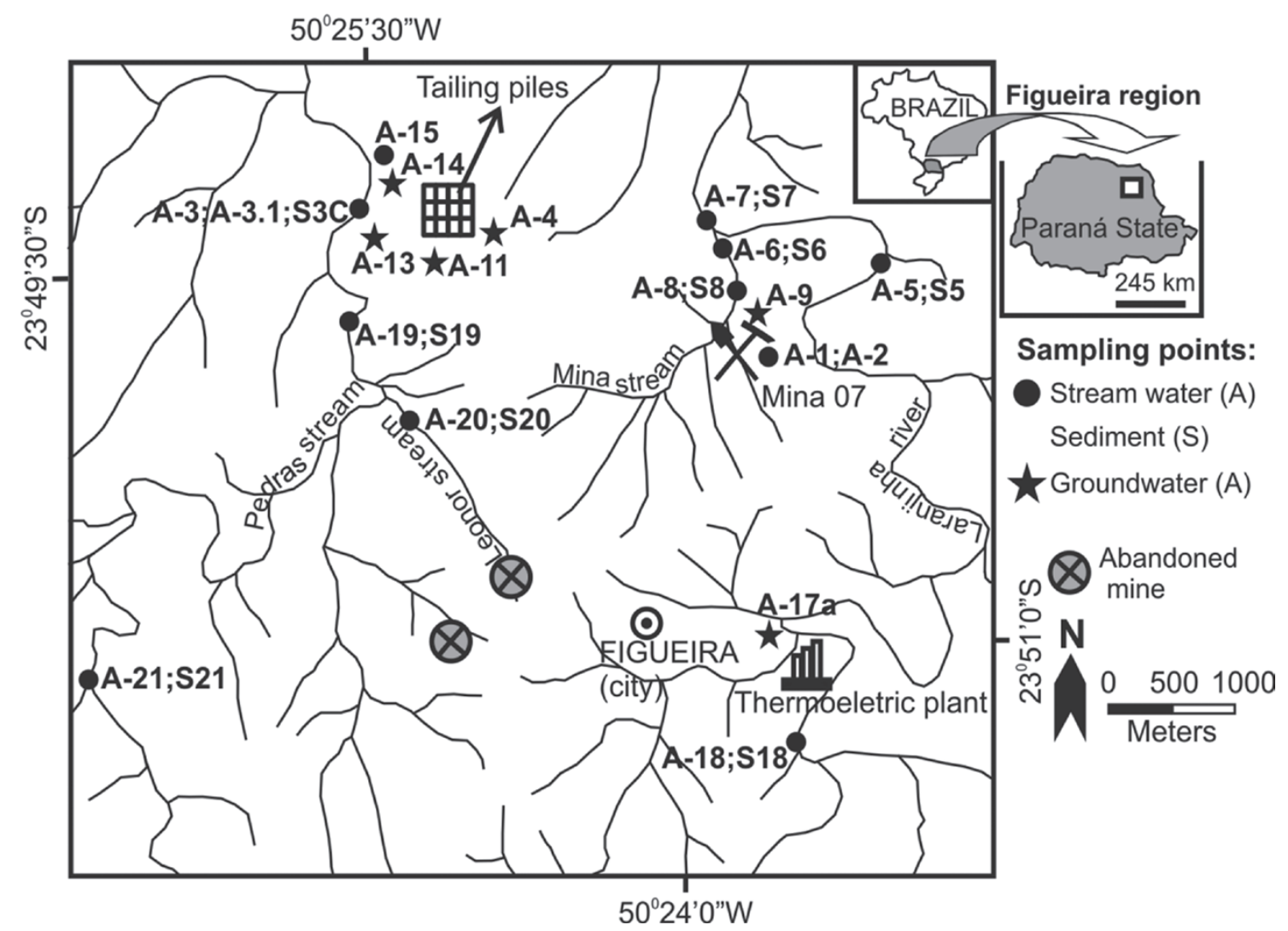

Figure 1 - Location of the sampling points in the study area. 


\section{MATERIALS AND METHODS}

SAMPLING AND ANALYTICAL PROCEDURE

Samples of surface and ground waters (5 to $10 \mathrm{~m}$ depth) were collected in September 2006, during the dry season (Fig. 1). A fraction of each sample was used to measure physico-chemical parameters (temperature, $\mathrm{pH}$ and redox potential) with specific electrodes and previously calibrated equipment. Combined platinum electrodes and combined glass electrodes were used to measure redox potential and $\mathrm{pH}$, respectively. In both, $\mathrm{Ag}: \mathrm{AgCl}$ $\left([\mathrm{KCl}]=3 \mathrm{~mol} \mathrm{~L}^{-1}\right)$ was the reference electrode. The Eh measurements were recalculated to the standard hydrogen potential (Standard Hydrogen Electrode - SHE), using the following equation (in $\mathrm{mV}$ ):

$\mathrm{Eh}_{\mathrm{SHE}}=\mathrm{Eh}_{\text {measured }}+209-0.7\left(\mathrm{t}-25^{\circ} \mathrm{C}\right)($ Equation 1$)$

The value 209 represents the potential SHE (at $25^{\circ} \mathrm{C}$ ) and 0.7 is a correction factor, which is a function of the Eh acquisition temperature $t$ (Nordstrom and Wilde 1998). Redox potential determination is not a simple task and no universally accepted procedures exist, especially for groundwater (Naudet et al. 2004). Regarding methodological limitations in determining precise and accurate redox potential values, the values presented in this study are taken as orders of magnitude equivalent to the real redox potential of each sample.

Alkalinity (considered for simplicity as $\mathrm{HCO}_{3}{ }^{-}$) was measured in stream water samples by tritation of $100 \mathrm{~mL}$ of the sample, using bromocresol blue as indicator and $\mathrm{H}_{2} \mathrm{SO}_{4}(0.16 \mathrm{~N}$ ) as reagent (Radojevic and Bashkim 1999).

For the analysis of cations and anions, each sample was filtered soon after sampling with a Millipore $^{\circledR}(0.22 \mu \mathrm{m}$-thick) membrane of cellulose acetate and divided in two aliquots. Only one of the aliquots (for the analysis of cations) was stabilized with suprapure $\mathrm{HNO}_{3}$ Merck ${ }^{\circledR}(1 \% \mathrm{v} / \mathrm{v})$
(Concas et al. 2006) and all samples were kept in PET bottles (Jardim and Fadini 2000) at $4{ }^{\circ} \mathrm{C}$.

In the same places where surface waters were collected, surface sediments (up to $3 \mathrm{~cm}$ depth) were sampled $(3 \mathrm{~kg})$ with a plastic shovel. In the laboratory, the sediment samples were homogenized and dried at $40{ }^{\circ} \mathrm{C}$. After that, a $200 \mathrm{~g}$ aliquot was sieved using nylon mesh sieves to separate the fraction $<63 \mu \mathrm{m}$ for analysis. This fraction was adopted in order to minimize the chemical dilution caused by the sand fraction (Luiz-Silva et al. 2006). Additionally samples of the neutralizing AMD agent generated in Mina 07 were collected (sieving tests showed that this product was totally composed of particles $<63 \mu \mathrm{m}$ in size).

Chloride and $\mathrm{SO}_{4}{ }^{2-}$ analyses in water samples were carried out by ion chromatography, whereas other techniques were used in cation analysis. The concentrations of $\mathrm{Al}, \mathrm{Ca}, \mathrm{Co}, \mathrm{Cr}, \mathrm{Fe}, \mathrm{Mg}, \mathrm{Mn}, \mathrm{Ni}$, and $\mathrm{Zn}$ were determined by inductively coupled plasma optic emission spectrometry (ICPOES). Arsenic, $\mathrm{Cu}, \mathrm{K}$, and $\mathrm{Na}$ were determined by flame atomic absorption spectrometry (FAAS), and $\mathrm{Cd}$ and $\mathrm{Pb}$ were determined by graphite furnace atomic absorption spectrometry (GFAAS). These elements were also analyzed in samples of the AMD acidity neutralizing product (commercial calcinated calcareous rock) following the same procedures used for sediments. Aluminum, As, Cd, Co, Cr, $\mathrm{Cu}, \mathrm{Fe}, \mathrm{Mn}, \mathrm{Ni}, \mathrm{Pb}$, and $\mathrm{Zn}$ contents in the silt-clay fraction of the sediments were determined after sample digestion in a $10 \mathrm{~mL}$ acid solution $(2: 2: 1: 1$ $\mathrm{H}_{2} \mathrm{O}-\mathrm{HF}-\mathrm{HClO}_{4}-\mathrm{HNO}_{3}$ ). The solutions were heated until fuming on a hot plate and taken to dryness. Then, $4 \mathrm{~mL} \mathrm{50 \%} \mathrm{HCl}$ was added to the residue and heated in a microwave. After cooling the solutions were made to a $10 \mathrm{~mL}$ volume with $5 \% \mathrm{HCl}$. These solutions were analyzed by means of a Perkin Elmer ICPMS. To check the quality of the analysis, certified reference materials (SEM 1640/NIST water and LKSD3/CANMET - sediment) were analyzed. The recovery values for all analyses of 
reference materials ranged between 90 and 105\% for all elements. Sample duplicates were also used, resulting in relative percentage differences lower than $15 \%$. Blanks (deionized water filtered through a $0.22 \mu \mathrm{m}$ membrane) were also prepared in order to take into account possible impurity of reagents and membranes. In this case, the concentrations of all analytes were close to or below the detection limits of the methods.

\section{DATA TREATMENT}

The chemical classification (Piper diagram) and the $\mathrm{CO}_{3}{ }^{2-}$ concentrations in stream waters were obtained by means of the GwCHART program (Winston 2000). The geochemical anomalies in the surface sediments were evaluated using an enrichment factor $\left(\mathrm{EF}_{\mathrm{s}}\right)$ based on the equation (modified after Gresens 1967):

$\mathrm{EF}_{\mathrm{s}}=\left(\mathrm{C}_{\mathrm{i}} / \mathrm{C}_{\mathrm{Al}}\right)_{\text {sample }} /\left(\mathrm{C}_{\mathrm{i}} / \mathrm{C}_{\mathrm{Al}}\right)_{\text {background }}$ (Equation 2)

We also used an enrichment factor for surface waters $\left(\mathrm{EF}_{\mathrm{w}}\right)$ based on the equation:

$\mathrm{EF}_{\mathrm{w}}=\left(\mathrm{C}_{\mathrm{i}} / \mathrm{C}_{\mathrm{Cl}}\right)_{\text {sample }} /\left(\mathrm{C}_{\mathrm{i}} / \mathrm{C}_{\mathrm{Cl}}\right)_{\text {background }}$ (Equation 3)

The $\mathrm{EF}_{\mathrm{s}}$ and $\mathrm{EF}_{\mathrm{w}}$ quantified the concentration of the element of interest $\left(\mathrm{C}_{\mathrm{i}}\right)$ in the sample, in relation to the (natural) geochemical background. In the sediments, the geogenic heterogeneities (effects caused by variations in grain size and mineral composition) were minimized using $\mathrm{Al}$ as the normalizing element (Cardoso et al. 2001, Luiz-Silva et al. 2006, 2008, Hortellani et al. 2008, Machado et al. 2008). The samples adopted as sediment and water background were those collected upstream the mining sites (S18 and S21; Fig. 1). With regards to $\mathrm{EF}_{\mathrm{w}}$, we adopted chlorine as the normalizing element because it is a conservative component in the geochemical processes (Faure 1998). Principal component analysis and Pearson correlation $(<0.05$ significance level $)$ were carried out to evaluate possible associations between variables (surface and ground water samples).
When the chemical concentration was below the detection limit we used half of this limit in the statistical procedures.

\section{RESULTS AND DISCUSSION}

\section{GeOchemistry of THE ACID Mine Drainage}

The physico-chemical parameters and the concentrations of the chemical constituents of the AMD from the tailings piles and Mina 07 are shown in Table I. In this table the compositional averages for the product used as AMD neutralizing agent in the study area are also shown. High $\mathrm{SO}_{4}{ }^{2-}$ (between 2592 and $9100 \mathrm{mg} \mathrm{L}^{-1}$ ) and Fe (between 294 and $2393 \mathrm{mg} \mathrm{L}^{-1}$ ) concentrations and the low $\mathrm{pH}$ values (3.2 to 4.6 ) in the water samples indicate pyrite oxidation in both sampling environments. In fact, redox potentials ranged between 445 and $628 \mathrm{mV}$, implying oxidizing conditions. The presence of $\mathrm{Al}$, As, $\mathrm{Ca}, \mathrm{Cd}, \mathrm{Co}, \mathrm{Cr}, \mathrm{Cu}, \mathrm{K}, \mathrm{Mg}, \mathrm{Mn}, \mathrm{Na}, \mathrm{Ni}, \mathrm{Pb}$, and $\mathrm{Zn}$ in the acid solutions results from leaching of minerals (especially silicates, oxides and sulfides) associated with the coal layers and host rocks (sandstones, siltstones, shales, and limestones). In the study area, coal and host rocks contain arsenic-rich pyrite and in much lower quantities galena $(\mathrm{PbS})$, sphalerite $(\mathrm{ZnS})$ and other sulfides (V.P. Campaner, unpublished data). Acid drainage from coal disposal piles (samples A-3.1 and A-15) presented particularly higher concentrations of $\mathrm{SO}_{4}{ }^{2-}, \mathrm{Al}, \mathrm{As}, \mathrm{Fe}, \mathrm{K}, \mathrm{Mg}, \mathrm{Mn}, \mathrm{Na}$, and $\mathrm{Zn}$ in relation to AMD from Mina 07 (samples A-1 and A-2). This can be a consequence of a larger exposure time of the fragmented material from the tailings to weathering, which has intensified pyrite oxidation (Cheng et al. 2009).

Sample A-2 represents the AMD that is treated with the calcinated calcareous rock $(\mathrm{CaO})$. After the neutralizing agent is added, this acid effluent is discharged in a natural drainage. In this case, the neutralization process proved to be inefficient for some parameters. According to 
TABLE I

Values of $\mathrm{pH}, \mathrm{Eh}(\mathrm{mV})$ and chemical concentrations in acid drainage (in $\mathrm{mg} \mathrm{L}^{-1}$ ) and neutralizing AMD agent ( $\mathrm{CaO}$ for commercial use made by calcareous sedimentary rock upon calcination; in $\mathrm{mg} \mathrm{kg}^{-1}$, except those indicated with \%). Values shown with the "less than" symbol ("<") are detection limits, and CONAMA (Environmental National Council) values (in $\mathrm{mg} \mathrm{L}^{-1}$, except $\mathrm{pH}$ ) are standards of effluent discharge (maximum permissible limits) of the Brazilian legislation (BRAZIL 2011).

\begin{tabular}{|c|c|c|c|c|c|c|}
\hline & \multicolumn{2}{|c|}{ AMD - Mina 07} & \multicolumn{2}{|c|}{ AMD - Tailings piles } & \multirow{2}{*}{$\begin{array}{l}\text { AMD neutralizing agent } \\
\qquad(\mathrm{n}=2)\end{array}$} & \multirow[b]{2}{*}{ CONAMA } \\
\hline & A-1 & A-2 & A-3.1 & A-15 & & \\
\hline pH & 3.2 & 4.6 & 3.3 & 4.1 & - & $5-9$ \\
\hline Eh & 625 & 445 & 628 & 478 & - & - \\
\hline $\mathrm{Cl}^{-}$ & 2.2 & 2.2 & 31 & 27.6 & - & - \\
\hline $\mathrm{SO}_{4}{ }^{2-}$ & 2969 & 2592 & 9100 & 8713 & - & - \\
\hline Al & 95.5 & 21.3 & 458 & 301 & $0.08 \pm 0.04$ & - \\
\hline As & 0.33 & 0.002 & 0.68 & 0.25 & $<0.2$ & 0.5 \\
\hline $\mathrm{Ca}$ & 393 & 554 & 418 & 449 & $27.1 \pm 0.3 \%$ & \\
\hline Cd & 0.11 & 0.06 & 0.04 & 0.03 & $0.26 \pm 0.04$ & 0.2 \\
\hline Co & 0.15 & 0.22 & $<0.05$ & $<0.05$ & $0.5 \pm 0.1$ & - \\
\hline $\mathrm{Cr}$ & 0.07 & $<0.02$ & 0.05 & 0.05 & $1.3 \pm 1.1$ & 0.5 \\
\hline $\mathbf{C u}$ & 0.08 & 0.03 & 0.03 & 0.04 & $0.82 \pm 0.07$ & 1 \\
\hline $\mathbf{F e}$ & 631 & 294 & 1937 & 2393 & $<0.02$ & 15 \\
\hline $\mathbf{K}$ & 3.59 & 4.04 & 20.5 & 40.1 & $0.06 \pm 0.01 \%$ & - \\
\hline Mg & 151 & 151 & 397 & 294 & $14.96 \pm 1.92 \%$ & - \\
\hline Mn & 12.8 & 9.55 & 40.4 & 31.7 & $67.5 \pm 14.8$ & 1 \\
\hline $\mathbf{N a}$ & 74.4 & 77.3 & 502 & 462 & $0.015 \pm 0.003 \%$ & - \\
\hline $\mathbf{N i}$ & 1.13 & 0.86 & 1.22 & 1.04 & $2.4 \pm 0.3$ & 2 \\
\hline $\mathbf{P b}$ & 0.001 & 0.0003 & 0.001 & 0.001 & $1.09 \pm 0.54$ & 0.5 \\
\hline Zn & 22.3 & 12.6 & 161 & 139 & $12.2 \pm 1.8$ & 5 \\
\hline
\end{tabular}

Table I, in addition to the $\mathrm{Ca}$ and $\mathrm{Mg}$, higher concentrations of trace elements $(\mathrm{Cd}, \mathrm{Co}, \mathrm{Cr}, \mathrm{Cu}$, $\mathrm{Mn}, \mathrm{Ni}$, and $\mathrm{Pb}$ ) were found in the neutralizing agent, and ions of these elements can be added to water during the AMD treatment (sample A-2). However, an efficient removal of elements such as $\mathrm{As}, \mathrm{Al}$ and $\mathrm{Cr}$ by precipitation was observed, as indicated by comparing samples A-1 and A-2 (Table I). The limiting values for the emission of effluents (Brazilian legislation) are listed in Table I. It may be noted that $\mathrm{pH}, \mathrm{Fe}, \mathrm{Mn}$, and $\mathrm{Zn}$ (and to a lesser extent As) levels found in the AMD of the study area do not comply with the Brazilian legislation, whereas $\mathrm{Cd}, \mathrm{Cr}, \mathrm{Cu}$, $\mathrm{Ni}$, and $\mathrm{Pb}$ concentrations are lower than the limiting values.

\section{GROUNDWATER}

Table II shows the variation of the chemical constituents, $\mathrm{pH}$ and $\mathrm{Eh}$ for the groundwater samples collected in piezometric wells (5 to $10 \mathrm{~m}$ in depth) and the limiting values from the Brazilian legislation for groundwaters. In general, redox potential (Eh) in the wells varied from suboxic $(241 \mathrm{mV})$ to very oxidizing $(767 \mathrm{mV})$ conditions. Some very oxidizing conditions recorded (e.g., $\mathrm{Eh}>500 \mathrm{mV}$, uncommon in groundwaters) could possibly be due to contamination with atmospheric oxygen during sampling and/or measurement (Naudet et al. 2004). The wells sampled downstream of the tailings piles (samples A-11, A-13 and A-14) show a pH interval (between 3.1 and 3.9) similar to the acid drainage generated in these tailings (Tables I and II). Significant $\mathrm{SO}_{4}{ }^{2-}, \mathrm{Al}, \mathrm{As}, \mathrm{Cd}, \mathrm{Co}$, 
$\mathrm{Cr}, \mathrm{Cu}, \mathrm{Fe}, \mathrm{Mn}, \mathrm{Ni}, \mathrm{Pb}$, and $\mathrm{Zn}$ concentrations in these wells could result from rainfall infiltration and subsequent leaching of mine wastes in the tailing deposits. Additionally, high $\mathrm{Ca}$ (107 to $448 \mathrm{mg} \mathrm{L}^{-1}$ ) and $\mathrm{Mg}$ (59.5 to $2095 \mathrm{mg} \mathrm{L}^{-1}$ ) concentrations were found in three wells sampled in the study area. Carbonate rocks present in the local stratigraphic sequence (Campaner and Luiz-Silva 2009) could be the mechanism controlling the high concentrations of these alkaline earth elements, although the low $\mathrm{pH}$ values and the presence of metals in solution suggest the occurrence of sulfide minerals oxidation, which makes neutralization difficult (Cravotta and Trahan 1999). The well located downstream of Mina 07 (sample A-9) showed concentrations lower than those for the acid drainage generated in the mine, despite the acid $\mathrm{pH}(4.1)$, oxidizing conditions $(\mathrm{Eh}=580 \mathrm{mV})$ and significant $\mathrm{SO}_{4}{ }^{2-}$ and metal (Al, $\mathrm{Cd}, \mathrm{Mn}$, and $\mathrm{Zn}$; Table II) concentrations have been identified.

In general, sulfate, $\mathrm{Al}, \mathrm{Cd}, \mathrm{Mn}, \mathrm{Ni}$, and occasionally $\mathrm{As}, \mathrm{Fe}, \mathrm{Na}$, and $\mathrm{Zn}$ contents, in groundwater wells studied exceeded the limits established by the Brazilian legislation (Table II). On the other hand, the AMD action at underground levels does not seem to have any influence in the groundwater extraction site for municipal public supply (upstream of coal mining sites; sample A-17a). It is revealed by the low metal levels and $\mathrm{pH}$ close to neutral, although $\mathrm{Cd}$ concentration slightly exceeded the limits adopted by the Brazilian legislation for groundwater (Table II).

TABLE II

Values of $\mathrm{pH}, \mathrm{Eh}(\mathrm{mV})$ and chemical concentrations (in $\left.\mathrm{mg} \mathrm{L}^{-1}\right)$ of groundwater samples from piezometric wells. Values shown with the "less than" symbol ("<") are detection limits, and CONAMA (Environmental National Council) values (in $\mathrm{mg} \mathrm{L}^{-1}$ ) are maximum permissible limits established by the Brazilian legislation in groundwater used for human consumption (BRAZIL 2008).

\begin{tabular}{|c|c|c|c|c|c|c|c|}
\hline & A-9 & A-4 & A-11 & A-13 & A-14 & A-17a & CONAMA \\
\hline pH & 4.1 & 5.5 & 3.9 & 3.1 & 3.2 & 7.5 & - \\
\hline Eh & 580 & 241 & 693 & 767 & 569 & 347 & \\
\hline $\mathrm{Cl}^{-}$ & 1.6 & 117 & 0.35 & 0.62 & 27.5 & 18.8 & 250 \\
\hline $\mathrm{SO}_{4}^{2-}$ & 229 & 9939 & 603 & 1584 & 12182 & 146 & 250 \\
\hline Al & 5.21 & 28.4 & 5.6 & 55.2 & 358 & 0.14 & 0.2 \\
\hline As & $<0.0006$ & 0.48 & $<0.0006$ & $<0.0006$ & 0.89 & $<0.0006$ & 0.01 \\
\hline $\mathrm{Ca}$ & 56.5 & 445 & 107 & 267 & 448 & 12.3 & \\
\hline Cd & 0.01 & 0.014 & 0.013 & 0.53 & 0.042 & 0.007 & 0.005 \\
\hline Co & $<0.05$ & $<0.05$ & 0.14 & 0.52 & $<0.05$ & $<0.05$ & - \\
\hline $\mathrm{Cr}$ & $<0.02$ & $<0.02$ & $<0.02$ & $<0.02$ & 0.05 & $<0.02$ & 0.05 \\
\hline $\mathrm{Cu}$ & $<0.01$ & 0.03 & $<0.01$ & 0.02 & 0.1 & $<0.01$ & 2 \\
\hline $\mathrm{Fe}$ & $<0.05$ & 1434 & $<0.05$ & 31.2 & 9484 & $<0.05$ & 0.3 \\
\hline $\mathbf{K}$ & 1.79 & 21.4 & 14.7 & 3.89 & 11.9 & 0.8 & \\
\hline Mg & 9.56 & 2095 & 59.5 & 69.1 & 355 & 2.13 & \\
\hline Mn & 0.45 & 42.7 & 14.8 & 34.2 & 59.8 & $<0.05$ & 0.1 \\
\hline $\mathrm{Na}$ & 10.6 & 1883 & 16.3 & 17.9 & 504 & 124 & 200 \\
\hline $\mathbf{N i}$ & $<0.08$ & 2.1 & 0.1 & 0.55 & 1.6 & $<0.08$ & 0.02 \\
\hline $\mathbf{P b}$ & 0.001 & 0.001 & 0.0008 & 0.003 & 0.01 & $<0.0003$ & 0.01 \\
\hline Zn & 0.47 & 16.9 & 0.49 & 10.1 & 164 & $<0.2$ & 5 \\
\hline
\end{tabular}




\section{STREAM WATER}

The physico-chemical parameters and chemical constituents of the surface water samples of the main river and streams that drain the coal mining area are shown in Table III together with the Brazilian legislation limiting values for stream waters. The surface waters presented a $\mathrm{pH}$ interval between 6 and 7.3, although, a higher value of 10.8 has been found in the Mina stream (see details below). Oxidizing conditions were observed with Eh varying between 394 and $425 \mathrm{mV}$, but in the Mina stream the redox potential was minor and ranged from 296 to $316 \mathrm{mV}$. In this last case, AMD treatment with $\mathrm{CaO}$ was used upstream and it could explain the lower Eh values found in the Mina stream. The $\mathrm{CaO}$ (lime) is considered to be a reducing agent due to the oxidation half-reaction:

$$
\left.\mathrm{CaO} \Leftrightarrow \mathrm{Ca}^{2+}+1 / 2 \mathrm{O}_{2} \quad \text { (Reaction } 1\right)
$$

During the AMD treatment, the loss (reaction 1) and gain of electrons is thought to occur simultaneously and the oxidation-reduction reaction among calcium hydroxide (produced by treating lime with water), oxygen and pyrite to produce calcium sulfate and iron hydroxide could be an example (reaction 2):

$$
8 \mathrm{Ca}(\mathrm{OH})_{2}+15 \mathrm{O}_{2}+4 \mathrm{FeS}_{2}+14 \mathrm{H}_{2} \mathrm{O} \Leftrightarrow 8 \mathrm{CaSO}_{4} \cdot 2 \mathrm{H}_{2} \mathrm{O}+4 \mathrm{Fe}(\mathrm{OH})_{3} \quad \text { (Reaction 2) }
$$

Although oxidation and reduction halfreactions occur simultaneously (e.g., reaction 2), they may have different kinetics. For instance, we observed in the study area that the introduction of $\mathrm{CaO}$ during the AMD treatment caused an Eh decrease from $400 \mathrm{mV}$ to values as low as $-100 \mathrm{mV}$ instantaneously. After some minutes the oxidizing process is started slowly and Eh reaches values between 30 and $90 \mathrm{mV}$ in approximately six hours. This condition could affect the redox potential in the slow-flowing Mina stream (see below), after the AMD discharge treatment.

In general, changes caused by AMD in the chemical composition of water systems were not very significant, but two groups of affected samples can be recognized in Piper diagram (Fig. 2). Group I samples are located farther from AMD sources and reveal chemical compositions resulting from weathering processes affecting regional rocks. Group II, on the other hand, represents water samples directly affected by AMD and is characterized by the location of the sampling points close to the coal mining sources (Fig. 1) and high $\mathrm{SO}_{4}^{2-}$ concentrations (Table III).

In the mixing zone between the AMD discharge from the coal disposal piles (sample A-3.1 - Table I) and the natural drainage (sample A-3, downstream from a mixing zone - Table III), the concentrations of $\mathrm{SO}_{4}{ }^{2-}, \mathrm{Al}, \mathrm{As}, \mathrm{Fe}, \mathrm{Mn}, \mathrm{Ni}$, and $\mathrm{Zn}$ were much lower than those found in the acid solution. In this case, precipitation and/or dilution of the chemical species are thought to occur naturally (Balistrieri et al. 2007). In Mina 07 mixing zone of acid drainage (sample A-2, Table I) with surface waters (sample A-8, downstream from a mixing zone), $\mathrm{SO}_{4}{ }^{2-}$ and concentrations of metals decreased in accordance to the distance from the AMD discharge point The extremely alkaline $\mathrm{pH}$ of sample A-6 (pH $=10.8$ ) suggests that the carbonate rocks present in the local stratigraphic sequence can play an important role. Natural attenuation of the AMD impact has been observed in the water system, attributed to interaction with limestone (Campaner and Luiz-Silva 2009), as also documented in other studies (Webb and Sasowsky 1994). In the study case, we thought that carbonate-rich groundwater recharge had a greater influence on the extremely alkaline $\mathrm{pH}$ because the work was done during the dry season and the drainage flow was slow (ca. $0.1 \mathrm{~m}^{3} \mathrm{~s}^{-1}$; V.P. Campaner, unpublished data).

Geochemical processes that are taking place in the study area could be explained by the 
TABLE III

Values of pH, Eh (mV) and chemical concentrations (in $\mathrm{mg} \mathrm{L}^{-1}$ ) of surface water samples. Values shown with the "less than"symbol ("<") are detection limits, and CONAMA (Environmental National Council) values (in $\mathrm{mg} \mathrm{L}^{-1}$, except $\mathrm{pH}$ ) are water quality standards (class 2) of the Brazilian legislation (BRAZIL 2005). Contents of $\mathrm{CO}_{3}{ }^{2-}$ were calculated by means of the GwCHART program (Winston 2000).

\begin{tabular}{|c|c|c|c|c|c|c|c|c|c|c|}
\hline & \multicolumn{2}{|c|}{ Mina stream } & \multicolumn{3}{|c|}{ Laranjinha river } & \multicolumn{3}{|c|}{ Pedras stream } & \multirow{2}{*}{$\begin{array}{c}\begin{array}{c}\text { Leonor } \\
\text { stream }\end{array} \\
\text { A-20 } \\
\end{array}$} & \multirow[b]{2}{*}{ CONAMA } \\
\hline & A-8 & A-6 & A-7 & A-5 & A-18 & A-3 & A-19 & A-21 & & \\
\hline pH & 6.4 & 10.8 & 7.3 & 6.2 & 7.2 & 6 & 7.1 & 6.6 & 6.8 & $6-9$ \\
\hline Eh & 316 & 296 & 394 & 412 & 417 & 420 & 427 & 425 & 411 & - \\
\hline $\mathrm{Cl}^{-}$ & 1.8 & 1.1 & 1.7 & 2.2 & 1.4 & 2.8 & 2.5 & 2.4 & 18 & 250 \\
\hline $\mathrm{CO}_{3}^{2-}$ & 0.0046 & 144.6 & 0.027 & 0.002 & 0.021 & 0.0018 & 0.029 & 0.0091 & 0.063 & - \\
\hline $\mathrm{HCO}_{3}^{-}$ & 39 & 49 & 29 & 27 & 29 & 39 & 49 & 49 & 215 & - \\
\hline $\mathrm{SO}_{4}{ }^{2^{-}}$ & 1587 & 773 & 12.6 & 14.4 & 2.3 & 75 & 62 & 6.8 & 994 & 250 \\
\hline Al & 0.07 & 1.7 & 0.27 & 0.24 & 0.4 & 0.42 & 0.33 & 0.41 & 1.2 & 0.1 \\
\hline As & $<0.0006$ & 0.0007 & 0.0013 & 0.0007 & $<0.0006$ & 0.0008 & 0.0008 & $<0.0006$ & 0.0018 & 0.01 \\
\hline $\mathrm{Ca}$ & 468 & 270 & 12.7 & 4.5 & 3.44 & 36.8 & 24.4 & 13.8 & 338 & - \\
\hline $\mathrm{Cd}$ & 0.014 & 0.005 & 0.0008 & 0.004 & 0.004 & 0.005 & 0.004 & 0.003 & 0.0007 & 0.001 \\
\hline $\mathrm{Co}$ & 0.06 & $<0.05$ & $<0.05$ & $<0.05$ & $<0.05$ & $<0.05$ & $<0.05$ & $<0.05$ & $<0.05$ & 0.05 \\
\hline $\mathrm{Cr}$ & $<0.02$ & $<0.02$ & $<0.02$ & $<0.02$ & $<0.02$ & $<0.02$ & $<0.02$ & $<0.02$ & $<0.02$ & 0.05 \\
\hline $\mathrm{Cu}$ & $<0.01$ & $<0.01$ & $<0.01$ & $<0.01$ & $<0.01$ & $<0.01$ & $<0.01$ & $<0.01$ & $<0.01$ & 0.009 \\
\hline $\mathrm{Fe}$ & 20.3 & 12.4 & $<0.05$ & $<0.05$ & $<0.05$ & 4.8 & $<0.05$ & 0.11 & 4.87 & 0.3 \\
\hline $\mathrm{K}$ & 3.45 & 2.25 & 3.56 & 3.86 & 3.16 & 5.38 & 4.89 & 4.29 & 9.92 & - \\
\hline $\mathrm{Mg}$ & 45.2 & 2.3 & 2.4 & 1.52 & 1.45 & 7.8 & 4.64 & 3.07 & 63.8 & - \\
\hline $\mathrm{Mn}$ & 2.3 & 0.05 & 0.07 & $<0.05$ & $<0.05$ & 0.87 & 0.59 & 0.05 & 31.8 & 0.1 \\
\hline $\mathrm{Na}$ & 49.9 & 33 & 4.01 & 3.47 & 3.32 & 8.03 & 7.3 & 6.7 & 34.7 & - \\
\hline $\mathrm{Ni}$ & 0.16 & $<0.08$ & $<0.08$ & $<0.08$ & $<0.08$ & $<0.08$ & $<0.08$ & $<0.08$ & $<0.08$ & 0.025 \\
\hline $\mathrm{Pb}$ & 0.0013 & $<0.0003$ & $<0.0003$ & $<0.0003$ & $<0.0003$ & 0.0007 & 0.0004 & $<0.0003$ & 0.0005 & 0.01 \\
\hline $\mathrm{Zn}$ & 3.8 & 3.6 & $<0.2$ & 0.3 & $<0.2$ & 0.19 & $<0.2$ & $<0.2$ & 0.07 & 0.18 \\
\hline
\end{tabular}

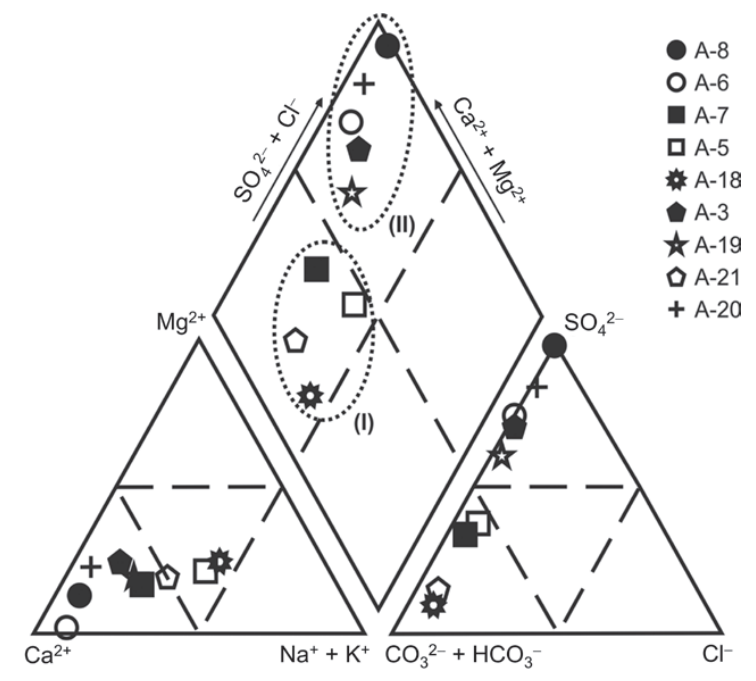

Figure 2 - Classification of stream waters of the study area, according to Piper diagram. Groups I and II refer to waters least and most affected by acid mine drainage, respectively. carbonate system that is complex and involves the transference of carbon among the solid, liquid and gaseous phases. According to the Law of Mass Action, the predominant carbonate species in solution are $\mathrm{H}_{2} \mathrm{CO}_{3}$ in $\mathrm{pH}<6.4, \mathrm{HCO}_{3}{ }^{-}$in 6.4 $<\mathrm{pH}<10.3$ and $\mathrm{CO}_{3}{ }^{2-}$ in $\mathrm{pH}>10.3$ (Krauskopf 1967). In the study area, the predominance of $\mathrm{CO}_{3}{ }^{2-}$ over $\mathrm{HCO}_{3}{ }^{-}$at $\mathrm{pH} 10.8$ (sample A-6; Table III) corroborates this fact. According to Garrels and Christ (1965), in areas where pyrite weathering occurs in the presence of carbonate rocks, the dissolution of calcite $\left[\mathrm{CaCO}_{3}\right]$ and dolomite $\left[\mathrm{CaMg}\left(\mathrm{CO}_{3}\right)_{2}\right]$ occurs in the presence of strong acids. In general, the $\mathrm{pH}$ of the solution tends to values close to neutral due to the $\mathrm{H}^{+}$consumption followed by the $\mathrm{H}_{2} \mathrm{CO}_{3}$ dissociation and the ion 
$\mathrm{HCO}_{3}{ }^{-}$stability in solution (Webb and Sasowsky 1994). Despite the fact that the relationship between carbonate species is controlled by $\mathrm{pH}$, the alkalinity in water systems may be strongly controlled by the dissolution rate of carbonate rocks in the environment (Hornberger and Brady 1998). This can explain the high $\mathrm{HCO}_{3}{ }^{-}\left(215 \mathrm{mg} \mathrm{L}^{-1}\right)$ levels in sample A-20, where the AMD influence is justified by the high $\mathrm{SO}_{4}{ }^{2-}$ concentration (994 $\mathrm{mg} \mathrm{L}^{-1}$ ). In general, the sulfate represents an important guide to identify the influence of AMD because it is not significantly affected by conventional acid effluent neutralization processes (Akcil and Koldas 2006). Iron and Mn concentrations in sample A-20 seem to be AMD remains, where physico-chemical conditions for the removal of these constituents occurred after the discharge of these waters $(\mathrm{pH}=$ 6.8) in another natural drainage of $\mathrm{pH} 7.1$ (sample A-19). At point A-19, the concentrations of all chemical constituents (except $\mathrm{SO}_{4}{ }^{2-}, \mathrm{Ca}$ and $\mathrm{Mn}$ ) are comparable to those of the sample situated upstream of the coal mining sites (sample A-21).

Samples located upstream from the AMD sources (A-21, A-7, A-5, and A-18) had low concentrations of chemical elements. The Laranjinha river (samples A-7, A-5 and A-18) flow rate during the dry season is ca. $20 \mathrm{~m}^{3} \mathrm{~s}^{-1}$ (V.P. Campaner, unpublished data) and it is the main source of public surface water supply in the study area. It yielded $\mathrm{pH}$ values and concentrations of chemical elements within the Brazilian standards, except for Al (Table III). Most surface water samples presented dissolved aluminum levels higher than Brazilian standards $\left(0.1 \mathrm{mg} \mathrm{L}^{-1}\right)$, ranging between 0.27 and $0.41 \mathrm{mg} \mathrm{L} \mathrm{L}^{-1}$, and occasionally $1.2 \mathrm{mg} \mathrm{L}^{-1}$ (Lenor stream) (Table III). This could be partly due to groundwater around the coal activity, with $\mathrm{Al}$ concentrations ranging from 5.21 to $358 \mathrm{mg} \mathrm{L}^{-1}$ (samples A-9, A-4, A-11, A-13, and A-14; Table II). In this case, aluminum solubility was strongly influenced by acid conditions in the groundwater because the metal precipitation is generally expected to occur within a $\mathrm{pH}$ interval of approximately 4.5-9.0 (Faure 1998). However, aluminum occurred in the dissolved phase in the surface water from rivers and streams of the study area with $\mathrm{pH}$ ranging from 6 to 7.3, including this area situated upstream from the coal activities. It is thought that $\mathrm{Al}$ can be adsorbed onto colloids ( 0.001 to $1 \mu \mathrm{m}$ particles). Although the water samples have been filtered using a $0.22 \mu \mathrm{m}$ membrane (conventional definition for dissolved materials), colloids are traditionally included within the dissolved fraction. However, colloids are not considered to be truly dissolved, even though some of them pass through a $0.22 \mu \mathrm{m}$ filter, and some operationally dissolved metals are considered to be "trapped" in colloidal aggregates (Bianchi 2007).

\section{STREAM AND GROUND WATER INTEGRATED TRENDS}

Principal component analysis (PCA) was performed to evaluate trace and major element trends in the whole datasets for surface and ground waters, as presented in Figure 3. The cumulative percentage of variation explained by the two main axes was $71.0 \%$. Therefore, further discussions will be limited to the highly meaningful components 1 and 2, which explained 52 and 19\%, respectively, of total data variance. Component 1 was especially marked by $\mathrm{pH}$ (more positive score) and sulfate (more negative score). Some elements presented negative correlation coefficients (r) with $\mathrm{pH}(\mathrm{Al}, \mathrm{As}, \mathrm{Ca}, \mathrm{Cr}$, $\mathrm{Cu}, \mathrm{Fe}, \mathrm{K}, \mathrm{Mn}, \mathrm{Ni}, \mathrm{Pb}$, and $\mathrm{Zn}$ ), with $\mathrm{r}$ ranging from -0.46 to $-0.60(p<0.05)$, except $\mathrm{Ca}(\mathrm{r}=-0.39), \mathrm{Fe}(\mathrm{r}$ $=-0.41)$ and $\mathrm{K}(\mathrm{r}=-0.14)$. These elements showed positive correlations with sulfate ( $\mathrm{r}$ ranging between 0.62 and $0.92 ; \mathrm{p}<0.05)$. Therefore, component 1 substantially explained the acidification effect on water chemistry. On the other hand, component 2 was mainly determined by two other groups of variables, including $\mathrm{Eh}, \mathrm{Co}$ and $\mathrm{Cd}$ (positively) and $\mathrm{Cl}^{-}, \mathrm{Mg}$ and $\mathrm{Na}$ (negatively), being this second group composed of elements $(r>0.97 ; p<0.05)$ of strong conservative behavior in water. The first 
group showed significant positive correlation $(\mathrm{p}<$ 0.05) between Co-Cd $(r=0.92)$, Co-Eh and Cd-Eh (both with $\mathrm{r}=0.60$ ). While the effect of $\mathrm{pH}$ alone on some metals such as cobalt is uncertain (ACMER 2005), this study showed that Co and Cd solubility was largely affected by redox conditions.

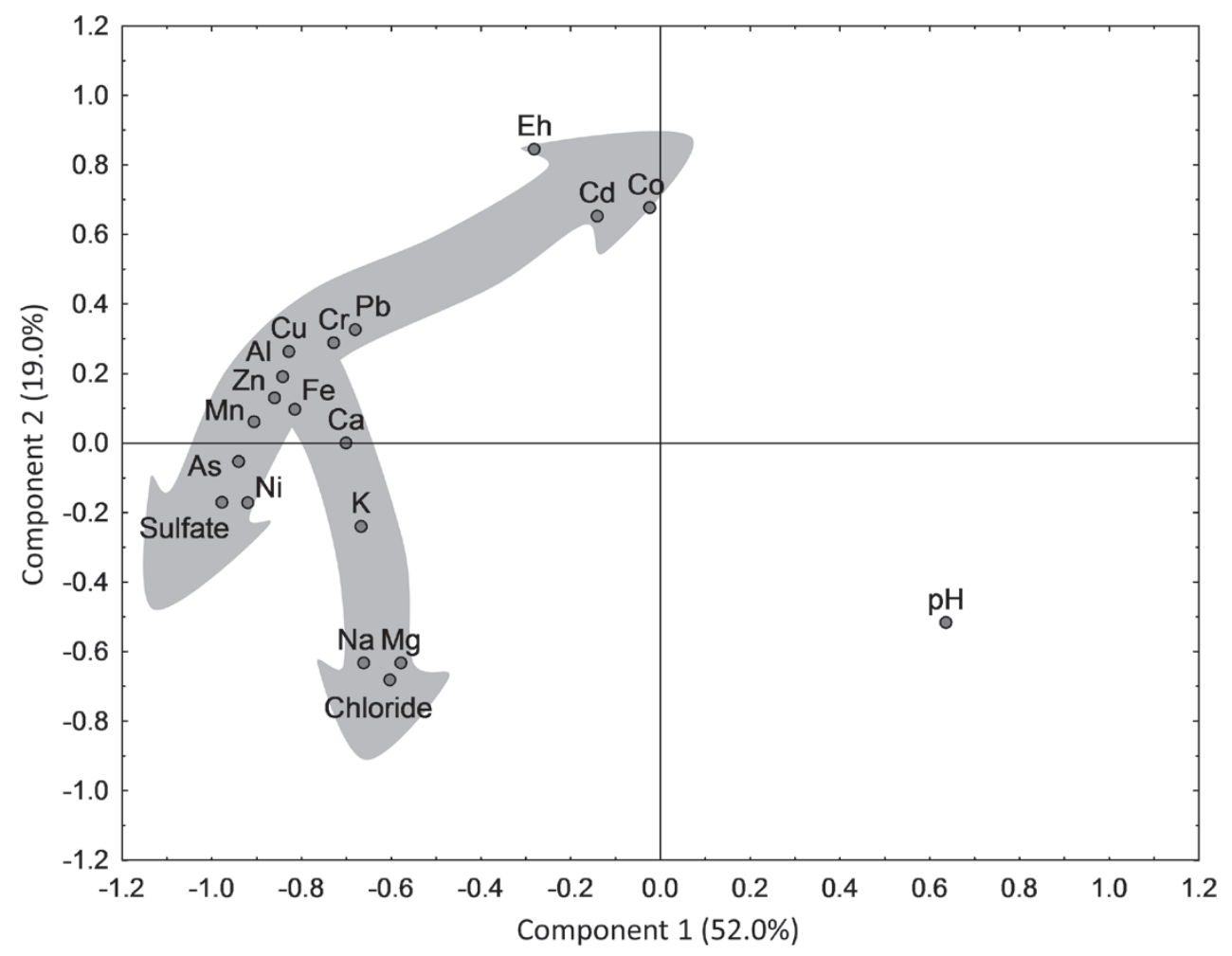

Figure 3 - PCA components 1 and 2 for surface and ground water data. Shaded arrows represent main association trends followed by major and trace elements (see text).

Two main distribution trends were observed in the PCA plot, represented by shaded arrows (Fig. 3). The major elements $\mathrm{Ca}, \mathrm{K}, \mathrm{Na}$, and $\mathrm{Mg}$ presented a trend of increasing proximity to $\mathrm{Cl}^{-}$(considered as the main indicator of a conservative behavior), However, $\mathrm{Ca}$ and $\mathrm{K}$ were predominantly affected by acidification processes (being significantly correlated with sulfate; $\mathrm{r}=0.70$ and 0.72 , respectively; $\mathrm{p}<0.05$ ), probably due to dissolution of carbonate (and $\mathrm{CaO}$ acting as a neutralizing agent) and feldspar-bearing rocks from the regional stratigraphic sequence, respectively. On the other hand, most elements seemed to follow a distribution trend, from higher association with sulfate to higher association with Eh: sulfate-NiAs-Mn-Fe-Zn-Al-Cu-Cr-Pb-Cd-Co-Eh. Besides, As, $\mathrm{Ni}$ and Mn also had significant positive correlations with chloride ( $\mathrm{r}$ ranging from 0.56 to 0.75 ). This analysis evidenced coupled effects of processes involving rock weathering, acid drainage, $\mathrm{pH}$, and $\mathrm{Eh}$. Furthermore, AMD effects on water chemistry can be attenuated by dilution processes resulting from a complex mixture of sources.

Although the correlation $(\mathrm{r}=0.80)$ between $\mathrm{Fe}$ (soluble) and $\mathrm{SO}_{4}{ }^{2-}$ was found to be high in the present study (AMD, stream and ground water samples), due to a common origin via iron sulfide (pyrite) oxidation, this relationship may not be linear. The following more detailed reactions show the key steps in pyrite oxidation forming $\mathrm{SO}_{4}{ }^{2-}, \mathrm{Fe}^{2+}$ and $\mathrm{Fe}^{3+}$ :

$\mathrm{FeS}_{2}+3 \frac{1 / 2}{2} \mathrm{O}_{2}+\mathrm{H}_{2} \mathrm{O} \Leftrightarrow \mathrm{Fe}^{2+}+2 \mathrm{SO}_{4}^{2-}+2 \mathrm{H}^{+}$ (Reaction 3) 


$$
\begin{array}{ll}
\mathrm{Fe}^{2+}+1 / 4 \mathrm{O}_{2}+\mathrm{H}^{+} \Leftrightarrow \mathrm{Fe}^{3+}+1 / 2 \mathrm{H}_{2} \mathrm{O} & \text { (Reaction 4) } \\
\mathrm{Fe}^{3+}+3 \mathrm{H}_{2} \mathrm{O} \Leftrightarrow \mathrm{Fe}(\mathrm{OH})_{3}+3 \mathrm{H}^{+} & \text {(Reaction 5) }
\end{array}
$$

Pyrite oxidation produces water-soluble components and acid $\left(\mathrm{H}^{+}\right.$; reaction 3$)$. The relatively reduced ferrous iron ions $\left(\mathrm{Fe}^{2+}\right)$ are further oxidized to form ferric iron $\left(\mathrm{Fe}^{3+}\right)$ and water $\left(\mathrm{H}^{+}\right.$is consumed; reaction 4). The kinetic of this reaction is $\mathrm{pH}$ dependent and proceeds slowly under acid conditions ( $\mathrm{pH}$ 2-3; ACMER 2005). This reaction can be accelerated by $\mathrm{Fe}$ oxidation, but in many cases, the oxidation of $\mathrm{Fe}^{2+}$ to $\mathrm{Fe}^{3+}$ may only proceed after the mine water has travelled several kilometers off site (ACMER 2005). The ferric iron $\left(\mathrm{Fe}^{3+}\right)$ formation in water results in the hydrolysis of iron to form ferric hydroxide $\left[\mathrm{Fe}(\mathrm{OH})_{3}\right]$ and acid $\left(\mathrm{H}^{+}\right)$(reaction 5). This reaction can promote accentuated removal of dissolved $\mathrm{Fe}$, without $\mathrm{SO}_{4}{ }^{2-}$ depletion, as possibly occurs in some sampling stations in the study area. A higher intensity of this process may explain the lower dissolved $\mathrm{Fe}$ in station A-9. Therefore, the relationship between dissolved $\mathrm{Fe}$ and $\mathrm{SO}_{4}{ }^{2-}$ in water may be largely dependent on the kinetics of the reactions involved. As a result, a high sulfate concentration does not imply necessarily in high $\mathrm{Fe}$ concentration.

\section{SEDIMENT GEOCHEMISTRY AND COMPARISON WITH}

WATER QUALITY

The concentrations of some metals and As in the fraction $<63 \mu \mathrm{m}$ of stream sediments are shown in Table IV. Among the elements analyzed, As (3.4 to $154 \mathrm{mg} \mathrm{kg}^{-1}$ ), $\mathrm{Cd}\left(0.11\right.$ to $2.09 \mathrm{mg} \mathrm{kg}^{-1}$ ), Co (6.6 to $\left.88.8 \mathrm{mg} \mathrm{kg}^{-1}\right)$, Fe (2.05 to $8.84 \%$ ), Mn (134 to $11876 \mathrm{mg} \mathrm{kg}^{-1}$ ), Ni (8.5 to $90.1 \mathrm{mg}$ $\mathrm{kg}^{-1}$ ), and $\mathrm{Zn}$ (40.0 to $518 \mathrm{mg} \mathrm{kg}^{-1}$ ) presented the largest variations (variation coefficients $>52 \%$ ). At sites S18 and S21, which are characterized by non-contaminated sediments, the As content in sediment was $3.4 \pm 0.3 \mathrm{mg} \mathrm{kg}^{-1}$, whereas at site $\mathrm{S} 3 \mathrm{c}$ (Pedras stream, next to the tailing piles from the coal mine) the As concentration in sediment reached $154 \mathrm{mg} \mathrm{kg}^{-1}$. Arsenic contents were also high in sediments at sites S20 (48.6 mg kg-1, Leonor stream downstream of the abandoned mine) and S8 (34.3 $\mathrm{mg} \mathrm{kg}^{-1}$, Mina stream, downstream of coal mine in activity). In addition, higher $\mathrm{Cd}$, $\mathrm{Co}, \mathrm{Fe}, \mathrm{Mn}, \mathrm{Ni}$, and $\mathrm{Zn}$ contents were recorded in sediments of the Pedras (S3c) and Leonor (S20) streams. So, along the study area, As, Cd, Co, $\mathrm{Fe}, \mathrm{Mn}, \mathrm{Ni}$, and $\mathrm{Zn}$ contents in stream sediments are strongly dependent on the proximity of the inflow from contaminated areas, with the most significant concentrations in sediments close to the tailing deposits and abandoned mines. Inflow from contaminated areas promoted high EF of As, $\mathrm{Cd}, \mathrm{Co}, \mathrm{Fe}, \mathrm{Mn}, \mathrm{Ni}$, and $\mathrm{Zn}$ in sediments (Table IV), with maximum values up to $12-28$ (As, Cd and $\mathrm{Mn}), 6-8(\mathrm{Co}, \mathrm{Ni}$ and $\mathrm{Zn})$ and $2.5(\mathrm{Fe})$. On the other hand, the variations in $\mathrm{Al}$ (3.48 to $6.43 \%$ ), $\mathrm{Cr}$ (23 to $\left.45 \mathrm{mg} \mathrm{kg}^{-1}\right), \mathrm{Cu}$ (12.9 to $30.3 \mathrm{mg} \mathrm{kg}^{-1}$ ), and $\mathrm{Pb}\left(14.7\right.$ to $\left.38.0 \mathrm{mg} \mathrm{kg}^{-1}\right)$ concentrations in fluvial sediments along the study area were less significant (variation coefficient $<32 \%$ ), with $\mathrm{EF}$ values $<1.6$ for the last three chemical elements (Table IV). These results were consistent with very low contents of $\mathrm{Cr}, \mathrm{Cu}$ and $\mathrm{Pb}$ in AMD (Table I).

For spatial comparisons of anthropogenic influences on trace elements from both surface waters $\left(\mathrm{EF}_{\mathrm{w}}\right)$ and sediments $\left(\mathrm{EF}_{\mathrm{s}}\right)$, enrichment factors (equations 2 and 3 ) in relation to average data from two reference sites taken as regional background levels (stations 18 and 21; Fig. 1) were used, as shown in Figure 4. Clear attenuation trends were observed for sediments from the Laranjinha river/Mina stream drainage systems in relation to As, $\mathrm{Cd}$ and $\mathrm{Zn}$, considering that sediments from station S8 represents the main anthropogenic source to stations S6 and S7 downstream. Sediments from Laranjinha river station 5 (representative of a noncontaminated condition) appear to dilute these contaminations at station S7. In these drainage systems, $\mathrm{Cd}, \mathrm{Co}, \mathrm{Pb}, \mathrm{Ni}$, and $\mathrm{Zn}$ concentrations in water also decreased with increasing distance 
TABLE IV

Total concentration of chemical constituents in stream sediments, background values (in $\mathrm{mg} \mathrm{kg}^{-1}$ unless otherwise indicated) and enrichment factors (EF).

\begin{tabular}{|c|c|c|c|c|c|c|c|c|c|}
\hline & \multicolumn{2}{|c|}{ Mina stream } & \multicolumn{2}{|c|}{ Laranjinha river } & \multicolumn{2}{|c|}{ Pedras stream } & \multirow{2}{*}{$\begin{array}{c}\text { Leonor stream } \\
\text { S20 }\end{array}$} & \multirow{2}{*}{$\begin{array}{l}\text { Background } \\
\text { S18 and S21 }\end{array}$} & \multirow{2}{*}{$\begin{array}{c}\text { EF } \\
\text { (interval) }\end{array}$} \\
\hline & S8 & S6 & S7 & S5 & S3c & S19 & & & \\
\hline Al (\%) & 4.44 & 5.67 & 5.43 & 6.43 & 5.72 & 4.04 & 5.99 & $3.48 \pm 0.71$ & - \\
\hline As & 34.3 & 16.4 & 13.1 & 10.5 & 154 & 14.6 & 48.6 & $3.4 \pm 0.3$ & $1.7-27.6$ \\
\hline Cd & 1.35 & 0.77 & 0.65 & 0.22 & 2.09 & 0.33 & 1.2 & $0.11 \pm 0.00$ & $1.1-11.6$ \\
\hline Co & 6.6 & 11 & 15.6 & 12.5 & 33.7 & 13.2 & 88.8 & $8.6 \pm 0.2$ & $0.6-6.0$ \\
\hline $\mathrm{Cr}$ & 24 & 39 & 30 & 45 & 35 & 28 & 30 & $23 \pm 6$ & $0.8-1.1$ \\
\hline $\mathrm{Cu}$ & 12.9 & 25.6 & 16.1 & 30.3 & 23.8 & 16.3 & 15.9 & $16.3 \pm 2.6$ & $0.6-1.0$ \\
\hline $\operatorname{Fe}(\%)$ & 3.71 & 4.35 & 2.85 & 3.22 & 6.18 & 2.79 & 8.84 & $2.05 \pm 0.13$ & $0.9-2.5$ \\
\hline Mn & 134 & 258 & 1295 & 776 & 2696 & 691 & 11876 & $466 \pm 29$ & $0.2-14.8$ \\
\hline $\mathbf{N i}$ & 14.6 & 22.3 & 17.2 & 16.3 & 24.3 & 11.7 & 90.1 & $8.5 \pm 2.6$ & $1.0-6.2$ \\
\hline $\mathbf{P b}$ & 22.7 & 22.4 & 32.2 & 21.1 & 38 & 19.8 & 32.5 & $14.7 \pm 0.3$ & $0.8-1.6$ \\
\hline Zn & 270 & 244 & 150 & 71.5 & 518 & 113 & 347 & $40.0 \pm 0.4$ & $1.0-7.9$ \\
\hline
\end{tabular}

downstream of the anthropogenic source. In contrast, a less clear trend was observed for As, with a lower $\mathrm{EF}_{\mathrm{w}}$ at station $\mathrm{A}-8$ than in stations $\mathrm{A}-5, \mathrm{~A}-6$ and A-7, suggesting lower As solubility close to the contamination source. Sediment and water enrichment factors below or close to 1 were found for $\mathrm{Cr}$ and $\mathrm{Cu}$ within such drainage systems, as well as for $\mathrm{Co}, \mathrm{Ni}$ and $\mathrm{Pb} \mathrm{EFs}$.

In the Pedras stream/Leonor stream drainage systems, while most elements remarkably showed water enrichment factor lower or close to 1 (just As presented an $\mathrm{EF}_{\mathrm{w}}$ exceeding 2 at stations A-3 and A-19, and As at station A-19; Fig. 4), sediment enrichment factor values exceeding 2 were found for most elements (As, $\mathrm{Cd}, \mathrm{Co}, \mathrm{Ni}$, and $\mathrm{Zn}$ ). These elements always showed lower $\mathrm{EF}_{\mathrm{s}}$ in the station S19, which receives the discharge from the uncontaminated section of the Pedras stream (Fig. 1). This contrast is expected because station $\mathrm{S} 3 \mathrm{c}$ (with maximum $\mathrm{EF}_{\mathrm{S}}$ for $\mathrm{As}, \mathrm{Cd}$ and $\mathrm{Zn}$ ) is closer to mining tailing piles, while station $\mathrm{S} 20$ (with maximum $\mathrm{EF}_{\mathrm{s}}$ for $\mathrm{Co}$ and $\mathrm{Ni}$ ) is closer to an abandoned mine upstream Leonor stream (Fig. 1). Contrarily to the Laranjinha river/ Mina stream drainage systems, the anthropogenic effect was stronger on the chemical composition of sediments than on the waters in the Pedras stream/
Leonor stream drainage systems, as indicated by enrichment factors. Possible explanations for this observation include probable differences in water flow rate (affecting dilution) and the fact that the mining activity within the Leonor stream drainage was abandoned.

When the scale of coal mining and related activities in the study area is taken into account, the environmental impact of mining and related activities on the stream sediments is relatively limited due to a high neutralizing capacity of the mining wastes which control the rapid precipitation of iron oxides and hydroxides as well as adsorption and/or co-precipitation of arsenic and trace metals. However, the observed high As and metals content in stream sediments close to the tailing deposits and abandoned mines may pose a potential environmental risk during accidental acid spikes, when significant fractions of As and metals in sediments can be re-mobilized.

\section{CONCLUSIONS}

The results of this study showed that acid drainage generated in the bituminous coal mining activities is a potential source of metals and As to water systems. The exposure of mining tailings to 

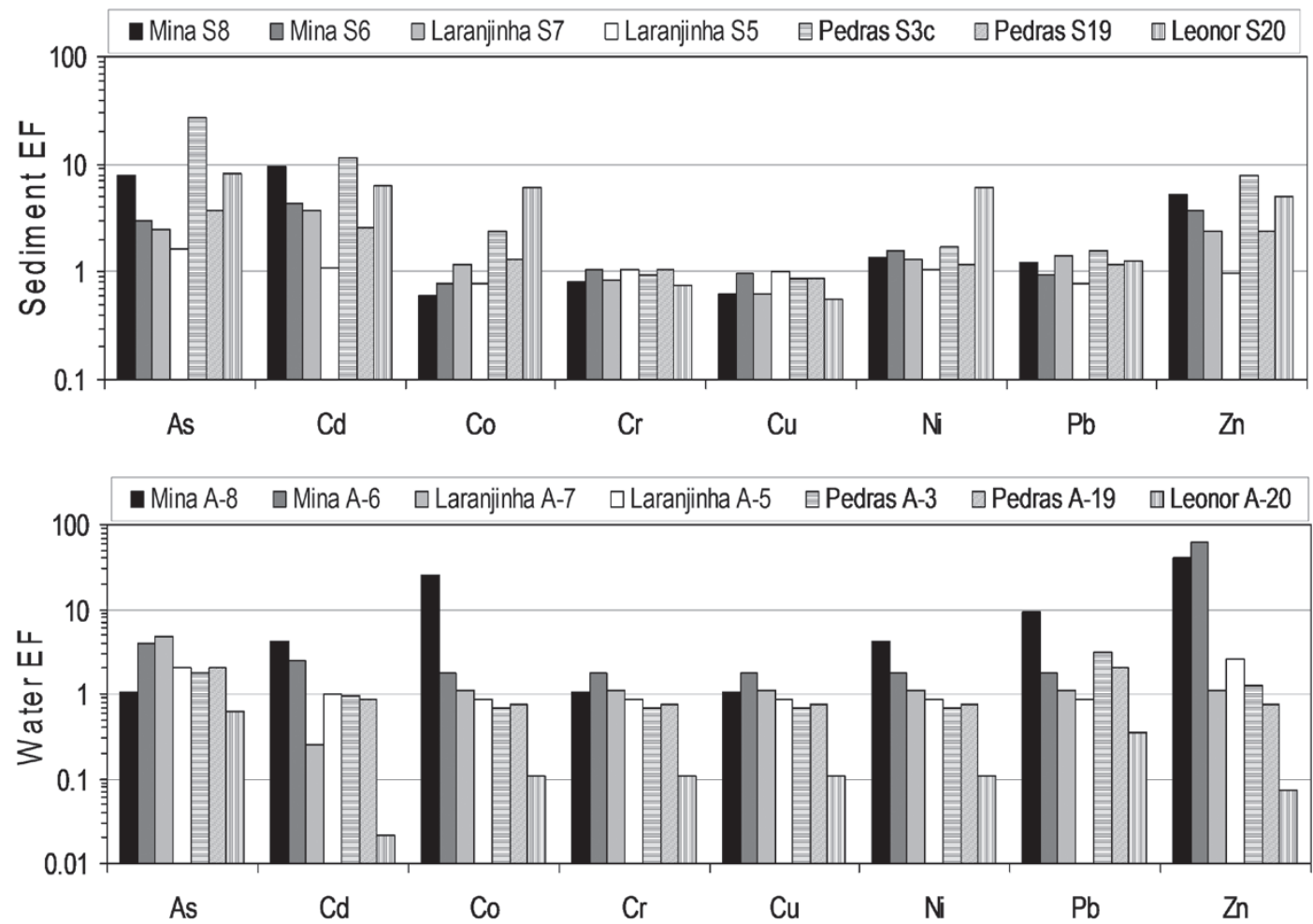

Figure 4 - Comparison of water enrichment factors (normalized to $\mathrm{Cl}^{-}$) and sediment enrichment factors (normalized to $\mathrm{Al}$ ) obtained for the same sampling stations located at the Mina, Pedras and Leonor streams and the Laranjinha river.

weathering produced acid solutions with the highest metals and As contents, influencing the chemical composition of surrounding groundwater. In stream waters, precipitation and dilution mechanisms attenuated the concentrations of the AMD chemical constituents. In some situations, the presence of carbonate rocks in the local stratigraphic sequences seems to have played an important role in decreasing the AMD regional impact. As well as in stream waters, metals and As geochemical anomalies in fluvial sediments occurred near the AMD sources due to precipitation mechanisms.

\section{ACKNOWLEDGMENTS}

The authors thank the Conselho Nacional de Desenvolvimento Científico e Tecnológico (CNPq, Brazilian agency) for the masters scholarship granted to V. P. Campaner; the Brazilian Nuclear Energy Commission (CNEN) for chemical analyses of water samples; and the company Carbonífera do Cambuí Ltda. for the logistics during field work; and the Dr. G. M. Garda for assistance with the text.

\section{RESUMO}

Influência de drenagem ácida sobre a qualidade de água e sedimento foi investigada em uma área de mineração de carvão (sul do Brasil). A drenagem ácida mostrou $\mathrm{pH}$ entre 3,2 e 4,6 e elevadas concentrações de sulfato, As e metais, dos quais, $\mathrm{Fe}, \mathrm{Mn}$ e $\mathrm{Zn}$ excederam os limites para emissão de efluentes da legislação brasileira. Arsênio também excedeu levemente o limite. Poços de monitoramento de água subterrânea situados em áreas de mina ativa e pilhas de rejeitos revelaram intervalo de $\mathrm{pH}$ e concentrações químicas semelhantes aqueles da drenagem ácida. Entretanto, amostras de águas subterrânea e de rio utilizadas para o abastecimento público municipal revelaram $\mathrm{pH}$ entre 7,2 e 7,5 e baixas concentrações químicas, embora a concentração 
de Cd tenha superado um pouco o limite adotado pela legislação brasileira para águas subterrâneas. Em geral, as águas de superfície mostraram grande intervalo de pH (6 a 10,8), e a influência da drenagem ácida em sua composição química não foi muito significativa. Localmente, drenagem ácida parece ter dissolvido rochas carbonáticas presentes na sequência estratigráfica local, atenuando a dispersão de metais e As. Anomalias destes elementos foram encontradas em sedimentos de corrente, e elas foram fortemente dependentes da proximidade de depósitos de rejeitos e minas abandonadas. Neste trabalho, processos de precipitação em sedimentos e diluição de fases dissolvidas foram considerados como os principais mecanismos responsáveis pela atenuação das concentrações de metais e As nas zonas de mistura entre drenagem ácida e água fluvial. Em geral, observou-se uma maior influência das atividades de mineração sobre a composição química de águas superficiais e sedimentos quando fatores de enriquecimento em relação aos níveis de background regionais foram utilizados.

Palavras-chave: drenagem ácida de mina, carvão, metais, qualidade de água.

\section{REFERENCES}

ACMER - Australian Centre For Minerals EXtension AND RESEARCH. 2005. A summary of passive and active treatment technologies for acid and metalliferous drainage (AMD). Available at <http://www.earthsystems.com. au/wp-content/uploads/2012/02/AMD Treatment Technologies_06.pdf $>$ (accessed 21.04.2013).

AKCIL A AND KoldAS S. 2006. Acid mine drainage (AMD): causes, treatment and case studies. J Cleaner Product 14: 1139-1145.

BAlistrieri LS, SEAl RR II, PiATAK NM AND PAUl B. 2007. Assessing the concentration, speciation, and toxicity of dissolved metals during mixing of acid-mine drainage and ambient river water downstream of the Elizabeth Copper Mine, Vermont, USA. Appl Geochem 22: 930-952.

BIANCHI TS. 2007. Biogeochemistry of estuaries. New York: Oxford University Press, 706 p.

BRAZIL - CONAMA. 2005. Environmental National Council. Resolução CONAMA n ${ }^{\circ} 357 / 2005$. Available at <http:// www.mma.gov.br/port/conama/res/res05/res35705.pdf> (accessed 06.06.2012).

BRAZIL - CONAMA. 2008. Environmental National Council. Resolução CONAMA n ${ }^{\circ}$ 396/2008. Available at <http:// www.mma.gov.br/port/conama/legiabre.cfm?codlegi=562> (accessed 06.06.2012).
BRAZIL - CONAMA. 2011. Environmental National Council. Resolução CONAMA n 430/2011. Available at <http:// www.mma.gov.br/port/conama/legiabre.cfm?codlegi=646> (accessed 30.01.2013).

BraZiL - Ministry of Mines And Energy. 2007. Plano decenal de expansão de energia 2007/2016. Available at $<$ http://www.epe.gov.br/PDEE/Forms/EPEEstudo.aspx> (accessed 06.07.2012).

Butler BA, RANVILlE JF AND Ross PE. 2008. Observed and modeled seasonal trends in dissolved and particulate $\mathrm{Cu}$, $\mathrm{Fe}, \mathrm{Mn}$, and $\mathrm{Zn}$ in a mining-impacted stream. Water Res 42: 3135-3145.

CAmpaner VP AND LuIZ-Silva W. 2009. Processos físicoquímicos em drenagem ácida de mina em mineração de carvão no sul do Brasil. Quim Nova 32: 146-152.

Cardoso AGA, Boaventura GR, Silva Filho EV AND BROD JA. 2001. Metal distribution in sediments from the Ribeira Bay, Rio de Janeiro - Brasil. J Braz Chem Soc 12: 767-774.

Cheng H, Hu Y, LuO J, Xu B AND ZHAO J. 2009. Geochemical processes controlling fate and transport of arsenic in acid mine drainage (AMD) and natural systems. J Hazard Mater 165: 13-26.

CHON HT AND Hwang JH. 2000. Geochemical characteristics of the acid mine drainage in the water system in the vicinity of the Dogye coal mine in Korea. Environ Geochem Health 22: 155-172.

Church CD, Wilkin RT, Alpers CN, RyE RO AND MCCLESKEY RB. 2007. Microbial sulfate reduction and metal attenuation in $\mathrm{pH} 4$ acid mine water. Geochem Trans 8: 1-14.

CONCAS A, ARdAu C, CRistini A, ZUdDAs P AND CAO G. 2006. Mobility of heavy metals from tailings to stream waters in a mining activity contaminated site. Chemosphere 63: 244-253.

CRAVOTTA III CA. 2008. Dissolved metals and associated constituents in abandoned coal-mine discharges, Pennsylvania, USA. Appl Geochem 23(Pt 2): 203-226.

CravotTA III CA, BRAdy KBC, Rose AW AND Douds JB. 1999. Frequency distribution of the $\mathrm{pH}$ of coal-mine drainage in Pennsylvania. In: MORGANWALP DW and BUXTON H (Eds), U.S. geological survey toxic substances hydrology program - Proceedings of the Technical Meeting. U.S. Geological Survey Water-Resources, Inv Rep 99-4018A, p. 313-324.

CRAVOTTA III CA AND TRAHAN MK. 1999. Limestone drains to increase $\mathrm{pH}$ and remove dissolved metals from acidic mine drainage. Appl Geochem 14: 581-606.

FAURE G. 1998. Principles and applications of geochemistry. $2^{\text {nd }}$ ed., Upper Saddle River: Prentice Hall, 600 p.

FUNGARO DA AND IZIDORO JC. 2006. Remediação de drenagem ácida de mina usando zeólitas sintetizadas a partir de cinzas leves de carvão. Quim Nova 29: 735-740.

GARRELS RM AND CHRIST CL. 1965. Solutions, minerals and equilibria. San Francisco: Freeman Cooper, 450 p. 
GOMES AJP, CRUZ PR AND BORGES LP. 2003. Recursos minerais energéticos: carvão e urânio. In: BIZZI LA, SCHOBBENHAUS C, VIDOTTI RM and GONÇALVES JH (Eds), Geologia, tectônica e recursos minerais do Brasil, Brasília: CPRM, p. 577-601.

GRESENS HL. 1967. Composition-volume relationships of metassomatism. Chem Geol 2: 47-65.

HoRnBERGER RJ AND BRADY KBC. 1998. Kinetic (leaching) testes for the prediction of mine drainage quality. In: BRADY KBC, SMITH MW and SCHUECK J (Eds), Coal mine drainage prediction and pollution prevention in Pennsylvania, Harrisburg: The Pennsylvania Department of Environment Protection, p. 1-54.

Horowitz A. 1991. A primer on sediment-trace element chemistry. Chelsea: Lewis Publishers, 136 p.

Hortellani MA, SARKIS JES, ABESSA DMS AND SOUSA ECPM. 2008. Avaliação da contaminação por elementos metálicos dos sedimentos do estuário Santos-São Vicente. Quim Nova 31: 10-19.

JARDIM WF AND FADINI PS. 2000. Storage of natural water samples for total and reactive mercury analyses in PET bottles. Analyst 125: 549-551.

JASPER A, UHL D, GUERRA-SOMMER M, HAMAD AMBA AND MACHADO NTG. 2011. Charcoal remains from a tonstein layer in the Faxinal Coalfield, Lower Permian, southern Paraná Basin, Brazil. An Acad Bras Cienc 83: 471-481.

KRAUSKOPF KB. 1967. Introduction to geochemistry. New York: McGraw-Hill, 721 p.

LARSEN D AND MANN R. 2005. Origin of high manganese concentrations in coal mine drainage, eastern Tennessee. J Geochem Explor 86: 143-163.

LEE JS AND CHON HT. 2006. Hydrogeochemical characteristics of acid mine drainage in the vicinity of an abandoned mine, Daduk Creek, Korea. J Geochem Explor 88: 37-40.

Luiz-Silva W, Machado W AND Matos RHR. 2008. Multielemental contamination and historic record in sediments from the Santos-Cubatão estuarine system, Brazil. J Braz Chem Soc 19: 1490-1500.

LUIZ-SILVA W, MATOS RHR, KRISTOSCH GC AND MACHADO W. 2006. Variabilidade espacial e sazonal da concentração de elementos-traço em sedimentos do sistema estuarino de Santos-Cubatão (SP). Quim Nova 29: 256-263.

Machado W, Luiz-Silva W, SAnders C And PatchineElam S. 2008. Coupled anthropogenic anomalies of radionuclides and major elements in estuarine sediments. J Environ Radioact 99: 1329-1334.

Moncur MC, PtACEK CJ, BLOWES DW AND JAMBOR JL. 2005. Release, transport and attenuation of metals from an old tailings impoundment. Appl Geochem 20: 639-559.

Morrone N AND DAEMON RF. 1985. Jazida de urânio de Figueira, Paraná. In: Schobbenhaus $\mathrm{C}$ and Coelho CES (Eds), Principais depósitos minerais do Brasil, Brasília: DNPM, p. 133-142.
NAUdet V, REVIL A, Rizzo E, BOTERro JY AND BÉGASSAT P. 2004. Groundwater redox conditions and conductivity in a contaminant plume from geoelectrical investigations. Hydrol Earth Syst Sc 8: 8-22.

NORDSTROM DK AND WILDE FD. 1998. National field manual for the collection of water-quality data-Reductionoxidation potential (electrode method): US Geologic Survey Techniques of Water-Resources Investigations, book 9, chap. A6, Denver: US Geologic Survey, 22 p.

PAMPÊO MLM, MoschinI-CARLOS V, ALEXANDRE NZ AND SANTO E. 2004. Qualidade da água em região alterada pela mineração de carvão na microbacia do rio Fiorita (Siderópolis, Estado de Santa Catarina, Brasil). Biol Sci 26: $125-136$

PAULSON AJ AND BALISTRIERI LS. 1999. Modeling removal of $\mathrm{Cd}, \mathrm{Cu}, \mathrm{Pb}$, and $\mathrm{Zn}$ in acidic groundwater during neutralization by ambient surface waters and groundwaters. Environ Sci Technol 33: 3850-3856.

RADOJEVIC M AND BASHKIM VN. 1999. Practical Environmental Analysis. Cambridge: Royal Society of Chemistry, $486 \mathrm{p}$.

RICARDI-BRANCO F, ARAI M AND RÖSLER O. 2002. Megaspores from coals of the Triunfo Member, Rio Bonito Formation (Lower Permian), northeastern Paraná State, Brazil. An Acad Bras Cienc 74: 491-503.

Rose AW, HaWkes HE AND WeBB JS. 1979. Geochemistry in mineral exploration. New York: Academic Press, 657 p.

SOARES ER, MELlo JWV, SchaEFER CEGR AND COSTA LM. 2006. Cinza e carbonato de cálcio na mitigação de drenagem ácida em estéril de mineração de carvão. R Bras Ci Solo 30(Section IX): 171-181.

STECKO JRP AND Bendell-Young LI. 2000. Contrasting the geochemistry of suspended particulate matter and deposited sediments within an estuary. Appl Geochem 15: 753-775.

STUMM W AND MORGAN JJ. 1996. Aquatic chemistry: chemical equilibria and rates in naturals waters. New York: J Wiley \& Sons Inc, $1022 \mathrm{p}$.

Teixeira EC, SAnchez JCD, Migliavacca D, Binotto RB AND FACHEL JMG. 2000. Environmental assessment: study of metals in fluvial sediments in sites impacted by coal processing and steel industry activities. Fuel 79: 1539-1546.

WEBB JA AND SASOWSKY ID. 1994. The interaction of acid mine drainage with a carbonate terrane: evidence from the Obey River, north-center Tennessee. J Hydrol 161: 327-346.

WiCKS CM AND GROVES CG. 1993. Acid mine drainage in carbonate terrains: geochemistry process and rates of calcite dissolution. J Hydrol 146: 13-27.

WINSTON RB. 2000. Graphical User Interface for MODFLOW. U.S. Geological Survey Open-File Report 00-315. 